\title{
UGT1A9 wt Allele
}

National Cancer Institute

\section{Source}

National Cancer Institute. UGT1A9 wt Allele. NCI Thesaurus. Code C105863.

Human UGT 1A9 wild-type allele is located in the vicinity of 2q37 and is approximately 101 kb in length. This allele, which encodes UDP-glucuronosyltransferase 1-9 protein, plays a role in the detoxification of phenolic compounds. 